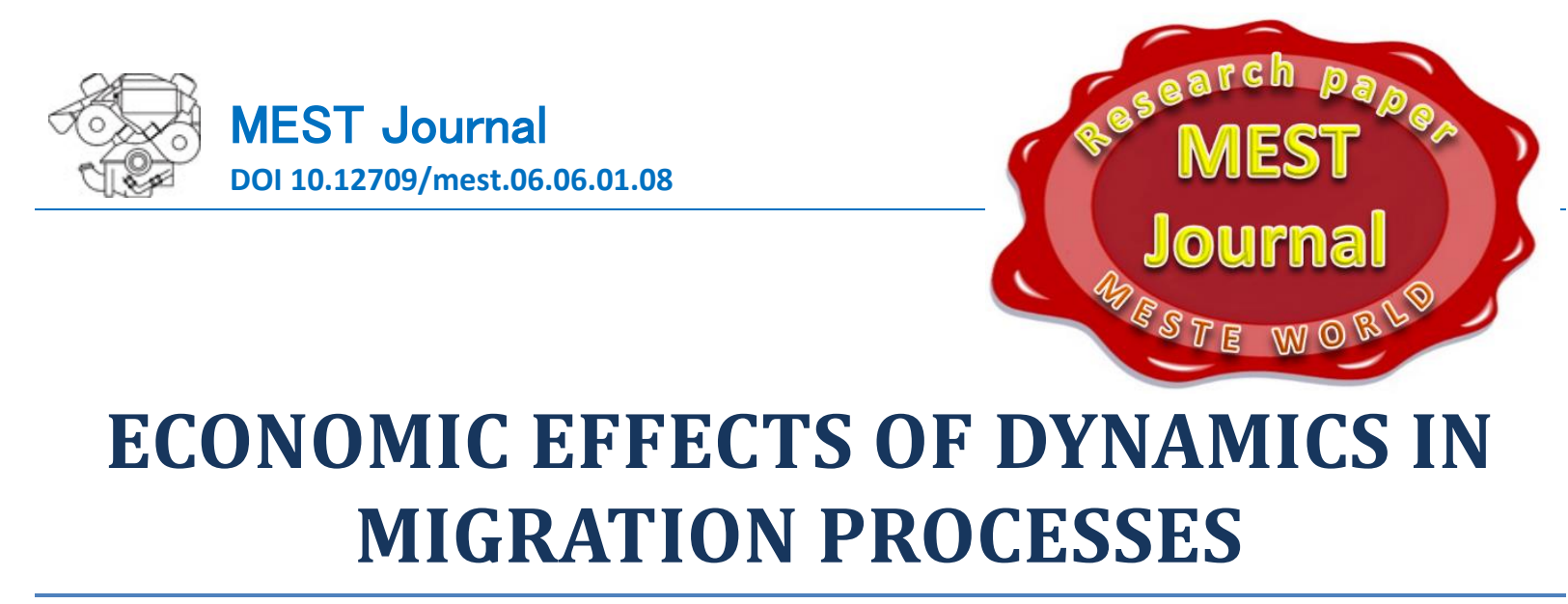

\title{
Tetyana Melnyk
}

Kyiv National University of Trade and Economics, Chair of International

Economic Relations, Kyiv, Ukraine

\section{Oksana Losheniuk}

Kyiv National University of Trade and Economics, Chair of International Economic Relations, Kyiv, Ukraine

\section{CMESTE}

JEL Category: F22, F24

\begin{abstract}
Considerable interstate movements of the labor force are taking place in nowadays world economy due to the reasons of economic and non-economic character. It makes the governments all over the world find mechanisms and take measures concerning the regulation of international labor migration. In this regard, it is impossible to use the complex approach of search without investigating the macroeconomic effect of this phenomenon to find out the major social and economic determinants. Economic effects have a significant impact on economies of donor and recipient countries. An important indicator for investigating the economic effect of international labor migration is money transfers. They cause redistribution of net benefits from emigration between labor importing and labor-exporting countries, as well as they, facilitate the GDP growth, the creation of new workplaces, investment processes and business development, and stimulate housing mortgage crediting. The negative effects of remittances on the economy of the donor country stipulate the stimulation of price increase on goods and services, the formation of the greater dependence of the donor country's economy on the labor force emigration, the reduction of probable governmental investments or foreign investments. In case of an appropriately constructed policy, the negative effects of international labor migration decrease while the positive impact on national economy increases. The article determines the effects of international labor migration and provides recommendations as for maximization of the positive impact of international labor migration on countries' economies all over the world.
\end{abstract}

Keywords: economic effects, remittances, international labor migration, emigration, transfers

\section{INTRODUCTION}

A significant impact on world economy leading to great interstate labor force movements causes the

Address of the corresponding author:

Oksana Losheniuk

埲: losheniuk@gmail.com reasons of economic and non-economic nature. The latter include political and religious reasons, integration and dissolution of states, natural 
disasters, wars, ecological problems and the reasons of a personal nature. Each of these and many other reasons can lead and do lead to the implementation of measures concerning the regulation of international labor migration.

However, the complex approach to searching the regulation mechanisms of international labor migration is impossible without investigating the macroeconomic effect of this phenomenon in order to find out the major social and economic determinants.

The object of the study is economic effects of dynamics in migration processes. The subject of the investigation is mechanisms and processes of international labor migration. The goal of the research is to determine the positive and negative impacts of international labor migration on donor and recipient countries. Here arises the need for finding out the scientific solution of the problems concerning the investigation of economic factors that influence the international labor migration as well as determining the positive and negative impacts of international labor migration on countries' economies all over the world.

In order to achieve the goal and solve the problems of the investigation the authors suggest the use of the following research methods: the method of logical generalization - to study the concepts of "economic effects", the essence and prerequisites of international labor migration; structurization - to systemize the economic factors influencing the international labor migration; statistical - to determine the dynamics of major indicators connected with international labor migration, labor migrants' remittances; comparison, analysis and synthesis - to generalize the approaches evaluating macroeconomic effects connected with the regulation of international labor migration.

Methodological approaches are applied in the study. The use of structural and functional approach is stipulated by the task to find the optimal decision as for overcoming the negative effects of international labor migration all over the world. For this purpose, the major factors forming the economic aspects of international labor migration all over the world are specified.

The system approach is used in order to determine the positive and negative effects of international labor migration in labor-importing and exporting countries. The major elements are formed and the interrelationships between them are established, as well as recommendations that will contribute to maximizing the positive impact of international labor migration on countries' national economies are determined.

Theoretical and methodological problems concerning economic effects of migration processes are elaborated by scientists, namely: the issues of the countries' economic positioning in terms of the impact of international migration were investigated by $S$. Hrynkevych, $Y$. Pakhomov, S. Pyrozhkov, T. Romashchenko, V. Oryeshkin; some aspects as for the impact of international labor migration on national labor markets of donor and recipient countries were described in scientific works of S.L. Brue, C.R. McConnell, D. W. MacPherson, L. Korchevska, E. Libanova, I. Olshevska, H. Hlushchenko, O. Rovenchak; the issues concerning the foreign migration management were analyzed by $A$. Haidutskyi, O. Malynovska, S. Metelyev, O. Polishchyuk. However, the consequences of international labor migration that must lower its negative effects and maximize the positive impact on the countries' national economies in the world need to be constantly corrected.

\section{FACTORS INFLUENCING THE ECONOMIC ASPECTS OF INTERNATIONAL LABOR MIGRATION}

In economic literature the economic effect is interpreted as the difference between the results and costs (Mochernyi, 2001), however, at the same time the assessment of economic effect of international labor migration can be given at different levels, in particular, at the level of a donor or recipient country; an individual or a household (Zayonchkovskaya, Molodikova, \& Mukomel, 2007).

The major factors influencing the analysis of economic aspects as for the international labor migration may be considered the following:

1. Migration costs. International migration involves costs connected with resettlement and transportation of personal property; alternative costs caused by profit losses during relocation and 
resettlement in a host country; costs connected with adaptation to new culture, language, climate, etc. If these costs exceed benefits which will be provided by high wages and salaries in a host country, the potential emigrant rejects emigration.

2. Unemployment. The frequent reasons of migration are not differences between the levels of wages and salaries in various countries, but chronic unemployment or part-time employment. Consequently, a certain country benefits from the emigration of unemployed people as they take no part in the creation of the country's national product and live due to transfer payments of working people. The citizens' well-being of this country will be increased by the sum of these transfer payments if unemployed people emigrate to other countries. And on the contrary, if migrant workers won't be able to find a job in a country and will get money for living due to working people, the average real profits of this country's workers will decrease.

3. Fiscal aspects. The immigrants' influence on tax revenues and state losses of a host country depends on the characteristics of these immigrants. If immigrants are young, qualified, educated, speak the language of a host country, they will find an appropriate job and will pay high taxes. If immigrants are unqualified, don't know the language, they will need the state or charitable assistance for some years in order to learn the language and assimilate.

4. Reverse flows. Returning to their home country emigrants bring great wealth and considerable work skills as well as managerial experience, which they will use in their countries after some period of time. Thus, reverse flows, i.e. the emigrants' comeback to their home countries after having earned money abroad, in the course of time change the interrelationships between benefits and losses in the countries. However, it often happens that emigrants having acquired experience and qualification stay in a host country. Moreover, mainly highly qualified workers leave the country, i.e. the "brain drain" leading to the decrease in technological potential of laborexporting countries and the decline of their general scientific and cultural level takes place.

5. Money transfers serve an important indicator for investigating the economic effect of international labor migration, their amount, dynamics and intended use acquiring a special meaning. The labor exporting country usually gets a peculiar kind of payment for such an export, i.e. it gets remittances. These remittances are the part of emigrants' profits that are transferred to their families staying in their home countries. This leads to redistribution of net benefit from emigration between labor exporting and labor importing countries. Remittances from emigrants working in another country will cause the growth of national product in it and, accordingly, losses of national product in the country of origin.

In 2015 , labor migrants transferred nearly $\$ 601$ billion to their relatives staying in home countries. The developing countries acquired $\$ 441$ billion from this sum; it is three times higher than the volumes of international financial aid (Migration and remittances, 2016).

The role of migrants' remittances at a macro-level is shown in contributing to GDP growth, primarily, by trade development and production of consumer goods due to demand increase stipulated by receiving remittances from abroad. The migrants' remittances also facilitate the creation of new workplaces, investment processes and, consequently, business development; in addition, they stimulate mortgage lending. The migrants' remittances have the positive impact on economies in donor countries of the labor force in terms of the increase in purchasing power at a macro level. They also facilitate the development of the economic sector producing consumer goods that, in its turn, favors the increase in the budget revenues, national revenues and the improvements in the country's balance of payments (Haidutskyi, 2010).

In general, a number of money transfers depends on three main factors: loan, insurance, and altruism. A number of transfers vary according to the dominated factor. In this regard, loan means regular payments aimed mainly at consumer prices. Insurance which is likely to have the form of accumulation is used by the members of the family in order to stabilize the economic situation in case of an economic crisis or force majeure circumstances. The altruistic approach is temporary since after some period of time a gradual reduction in the amounts of remittances occurs (Poirine, 1997). 
The major factors influencing the volumes of labor migrants' money transfers are considered to be the migrant's level of education and qualification. Together with the growth of the labor migrant's level of education the volumes of his remittances increase correspondingly, an intensive growth in the volumes of money transfers taking place among migrants who have studied more than 17 years (Bollard). However, it is still a debating point in scientific literature since some investigators taking into consideration the migrants' level of education, the income level in a donor country of labor migration, the development of financial sector and expected rates of economic growth prove that the total volume of the labor migrants' remittances reduces together with the increase in the number of migrants with higher education (Migration models).

Under conditions of excess supply of highly qualified workers in the domestic market, the international migration of the part of them doesn't have any negative impact on the economy of a donor country. In such a case, the "brain drain" is sure to stimulate the loss of a certain part of highly qualified workers, nevertheless under conditions of high supply in the national labor market this negative effect is compensated by additional training of new generations of highly qualified labor force by the national system of education due to the migrants' remittances (Skilled immigration in OECD regions).

The labor migrants' money transfers have two opposite economic impacts on the state of employment in the labor market of a donor country. Firstly, the unemployment level may increase if the receivers of these revenues will consider them to be one of the forms of social benefits. Secondly, foreign revenues reduce the interest rate and, therefore, encourage firms to increase investments that facilitate the creation of new workplaces. That is why the total economic effect will depend on which of these two impacts will dominate (Drinkwater).

In Ukraine, labor migration through money transfers has a significant impact on a series of economic processes in a donor country having, in such a way, an indirect impact on the GDP. The use of transfers in order to increase the educational level of the receivers of these transfers in the long term may lead to the growth of labor capital and compensate all previous economic losses (Shevchuk).

The main channels of getting money transfers are international payment systems (such as the Western Union, "Zolotaya Korona", MoneyGram, etc.) and the correspondent bank accounts. However, according to official statistics, the importance of international payment systems as a channel of getting money transfers increased from $37 \%$ at the beginning of 2011 to $53 \%$ in 2015 due to the reduction of the part of the banking system. After the loss of popularity and implementation of a tougher currency policy by the NBU, the international payment systems became again the biggest channel of getting money transfers in 2016 (Slobodian, 2015).

There is a great volume of not only official remittances but unofficial ones as well. Despite the fact that there are no precise measurements, it is noted that the volume of the latter may be compared to official ones (Kolosnitsyna, 2005). Nearly \$250-300 billion of migrants' international money transfers are beyond official statistics since they do it through different unofficial channels (Haidutskyi, 2010). Low popularity of remittances through official channels is stipulated by lack of public confidence in the banking system as a whole, unwillingness to show real profits and insufficient financial literacy of the population. As the experience of other countries shows, the increase in volumes of remittances transferred through official channels increases the ability of the banks' lending to enterprises and, in such a way, economic growth has to be stimulated (Slobodian, 2015).

At the beginning of the $3^{\text {rd }}$ century, the volumes of labor migrants' remittances to developing countries exceeded the scope of international technical aid from international financial organizations, and volumes of portfolio investments were practically equal to the scope of direct investments (Libanova \& Paliy, 2004). This proves that the financial flow created by labor migrants' remittances is one of the largest and it links the developing countries with the world economic system.

It is generally admitted that the migrants' remittances make a positive external economic effect since they increase the GNP. In economies of many countries, not only in the low-income 
developing countries but in the middle-income countries as well (Greece, Turkey, Portugal), the migrants' remittances are a significant augmentation of national income (Kolosnitsyna, 2005) and additional means of combating poverty in labor donor countries. The migrants' remittances are generally transferred in foreign currencies that improve the state of the balance of payments. Thus, the migrant workers' remittances to their home countries make two positive economic effects.

The additional positive effect from migrants' remittances on the donor country's economy relates to availability in some cases of a multiplier effect from such additional currency revenues. However, the existence of such a multiplier effect and its extent depends on the intended use of the migrants' money received in their home countries. It is worth noting that remittances not only lower the poverty level of migrants' families increase their income, but in case of multiplication they have a positive effect on the overall state of the country's economy and, consequently, on the population of a donor country.

However, there exist negative impacts of remittances on the donor country's economy. The most widespread is the effect of stimulating the price increases on goods and services if the supply of the latter in the national (regional, local) markets is fixed or limited. It concerns, for instance, such goods as land or real estate. In particular, in some countries, the prices of land are usually higher in the regions with a great number of inhabitants working abroad. The less widespread negative effect of migrants' remittances on the donor country's economy is the formation of a greater dependence on the donor country's economy on the emigration of the labor force, the reduction of probable governmental investments or foreign investments.

The negative impact of international labor migration on the donor country' economy is that due to prevailing illegal component migrants don't participate in formation of social funds that increases financial tension of the population's social security in a donor country, and in case of people's returning home at the retirement age arises the problem of their pension payments that may cause the social discontent in the society.
The immigration problem is complicated by a range of noneconomic factors. Mass migration is always accompanied by the increase of social tension in the society, criminality, conflicts on the racial, national or religious grounds and other phenomena.

Thus, labor migration has both positive and negative sides, moreover, "pluses" and "minuses" will be different for recipient and donor countries.

\section{POSITIVE AND NEGATIVE EFFECTS OF INTERNATIONAL LABOR MIGRATION}

The positive effects of labor migration for labor importing country include the aspects shown in figure 1.

Mitigation of employment problem due to the liquidation of the labor force deficit. Lack of labor resources may significantly hamper the country's economic growth. According to the Public Employment Service, the employers informed the employment centers that the number of vacancies in Ukraine accounted for 34 thousand on the first of December in 2015, and compared to the corresponding date it decreased by a quarter in 2016 (State Statistics Service of Ukraine, n.d.).

Stimulation of additional employment, the creation of additional workplaces and development of infrastructure caused by foreign workers' demand for goods and services.

Improvement of the population's living standards and quality of life, building construction and agriculture due to labor migrants' minimal requirements in choosing jobs that are not attractive for the local population.

Quality improvement of the local labor force. For that reason, attraction of migrant workers with low educational and qualification levels stimulates the local population to be engaged in more intellectual work, i.e. it contributes to their vertical mobility.

Saving on training (in case of qualified workers' attraction). Highly qualified specialists who received education in other countries bring "net income" to receiving communities that allows getting more return without preliminary expenses. 


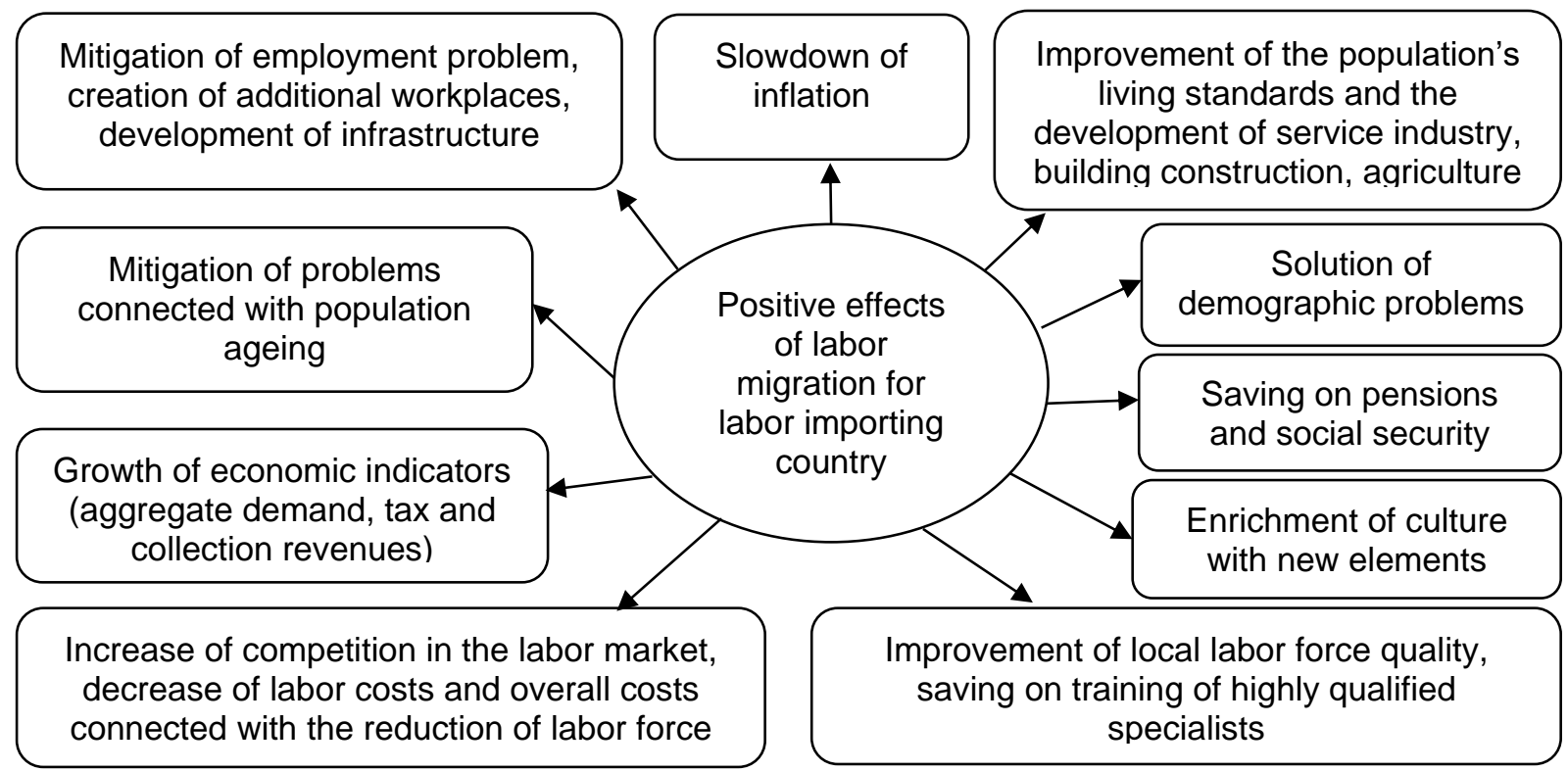

Fig. 1. Positive effects of international labor migration for labor importing country

Increase of labor productivity and efficiency, the competitiveness growth of goods produced by a country due to created prerequisites for attracting foreign investments because of the lower price of migrants' labor force, as well as introduction of new technologies, multiplier effect due to production growth and reduction of production costs (Zayonchkovskaya, Molodikova, \& Mukomel, 2007).

A solution of demographic problems. Because of a difficult political situation, the number of emigrants from Ukraine has grown. During the period from January to October in 2015, the number of people who left the country was nearly 431 thousand of persons. Thus, the number of potential employable population of Ukraine decreases significantly (State Statistics Service of Ukraine, n.d.). For that reason, the migrants' attraction must be considered as the most optimal way of labor resources recruitment for future innovative development of Ukrainian economy. The evidence as for the competence of such a strategy is the experience of developed economies: the $\mathrm{EU}$ is planning to attract 40 million of migrants by 2050 , the USA - nearly 100 million of people (Sytarchuk, 2010).

The growth of the host country's economic indicators (an aggregate demand; increase of budget revenues due to taxes and collections).

The slowdown of inflation due to foreign workers' stronger leaning to save money.
Mitigation of problems connected with population aging, especially in case of families' migration.

Migrants enrich the host country's culture with new elements contributing to the development of tolerance among local inhabitants (Slobodian, 2015).

Saving on pensions and other social security payments (in case of a temporary migration) (Libanova \& Paliy, 2004).

However, a recipient country of labor migration will inevitably face the negative effects of labor migration. The most important of them is the shown in figure 2.

Dumping in the labor market and service industry that leads to the wage cuts of social workers. Foreign scientists point out that a great influx of labor migrants into the economy of the USA caused neither significant growth of unemployment nor wage cuts of social workers. This is stipulated by the fact that migrants perform low-skilled work while qualified workers don't feel an effect of competition from other countries' labor immigrants (Sytarchuk, 2010).

The increase of workplace competition, a complication of the situation in the domestic labor market and the marginalization of less qualified workers are caused by the fact that migrants occupy workplaces performing such a work that could be done by local population. 


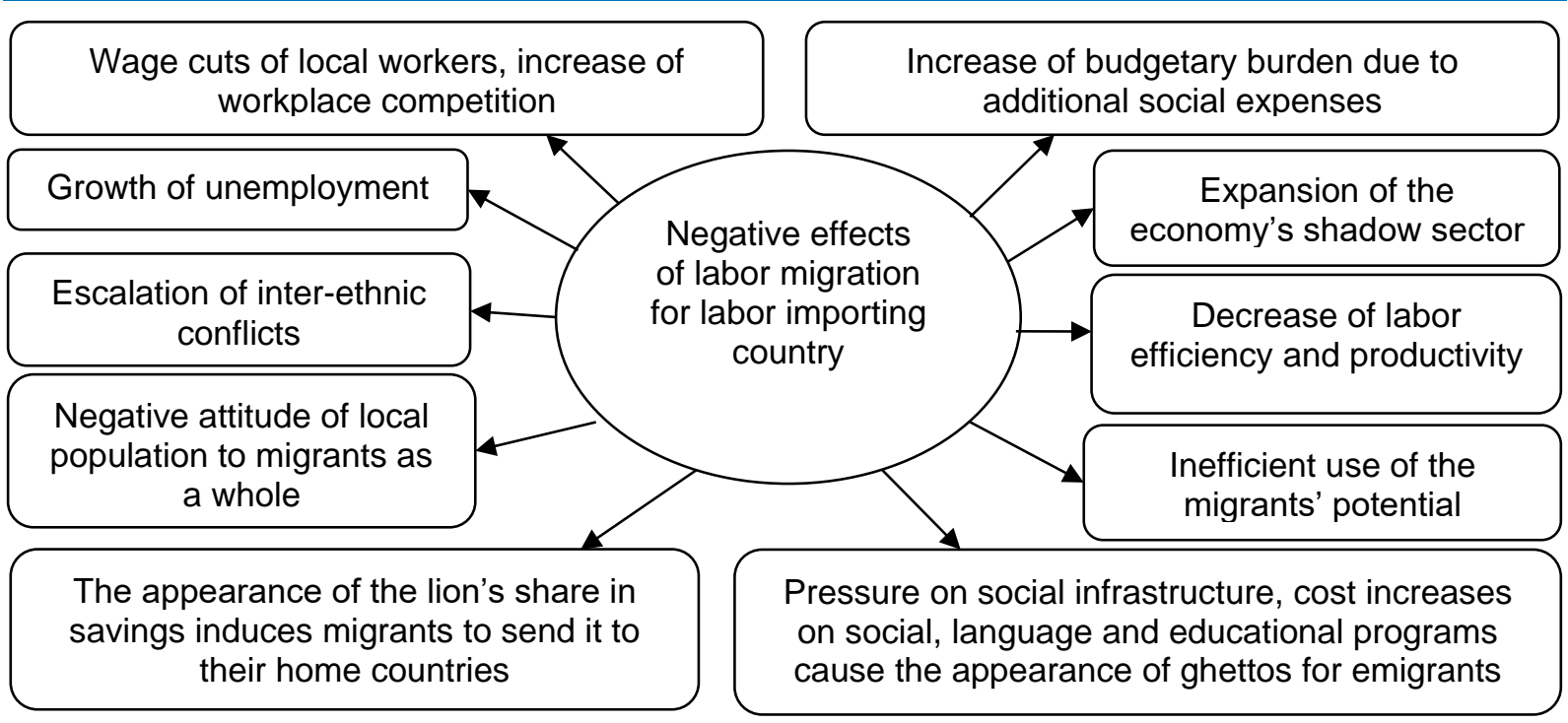

Fig. 2. Negative effects of international labor migration for labor importing country

The growth of unemployment caused by the mass influx of migrants. The number of unemployed persons in Ukraine accounted for 1,7 million people in the first half-year of 2015 . According to ILO methodology the level of unemployment was $9,2 \%$, and among the working-age persons, it accounted for $9,6 \%$ of the economically active population. Among the young people under the age of 25 , the level of unemployment is more than twice higher than the country's average indicator of the economically active population that accounts for $21,3 \%$. The indicators of unemployment in Ukraine don't differ much from the average indicators in the EU. So, among the population of all age groups, the average unemployment level accounted for 9,6\% in EU countries, in particular, among the young people under the age of 25 it was 20,6\% (The Major Tendencies in the Labour Market, 2015).

Migrants exerting pressure on social infrastructure accompanied by complications connected with housing problems as well as increasing costs of social, language and educational programs are the reason for the migrants' ghettos appearance (Kolosnitsyna, 2005).

The decrease of labor efficiency and productivity because of the problems connected with the introduction of labor-saving technologies that are caused by the use of cheaper labor force.

The increase of budgetary burden due to additional social expenses (primarily, in case of constant migration, families' migration and availability of "strong share of unemployment" (Sytarchuk, 2010).

Migrants send the lion's share of the savings to their home countries that don't contribute to the growth of their solvent demand in a host country and to reinvestments into the recipient country's economy (Zagulyaev, 2010).

The spontaneous influx of labor migrants and the absence of coordination between supply and real demand for the labor force cause inefficient use of the migrants' potential because of their concentration in those places where one can earn money quickly and illegally rather than in specific sectors and regions. For that reason, there is a need for the additional labor force.

Expansion of the economy's shadow sector. Large-scale economic and criminal offenses (smuggling, illegal financial operations) take place. For that reason, the state has to bear additional costs in order to neutralize criminalization (primarily, in case of illegal migration).

Not all investigators view improvement in the demographic state of the labor-importing countries as a positive effect. Some authors consider that the source of profit is intellect rather than labor; labor is only the method of intellectual realization. Thus, improvement in the demographic state of a country is possible only due to the attraction of "intellect-bearing" labor resources (Zagulyaev, 2010). 
Negative attitude of the local population to migrants as a whole.

Escalation of inter-ethnic conflicts. Migrants may completely deny the host country's culture and try to impose their own one provoking in such a way inter-ethnic conflicts (Zayonchkovskaya, Molodikova, \& Mukomel, 2007).

Just like the labor-importing country the labor exporting country also faces the negative and positive effects of labor migration. The latter include the following aspects (see Figure 3 ):

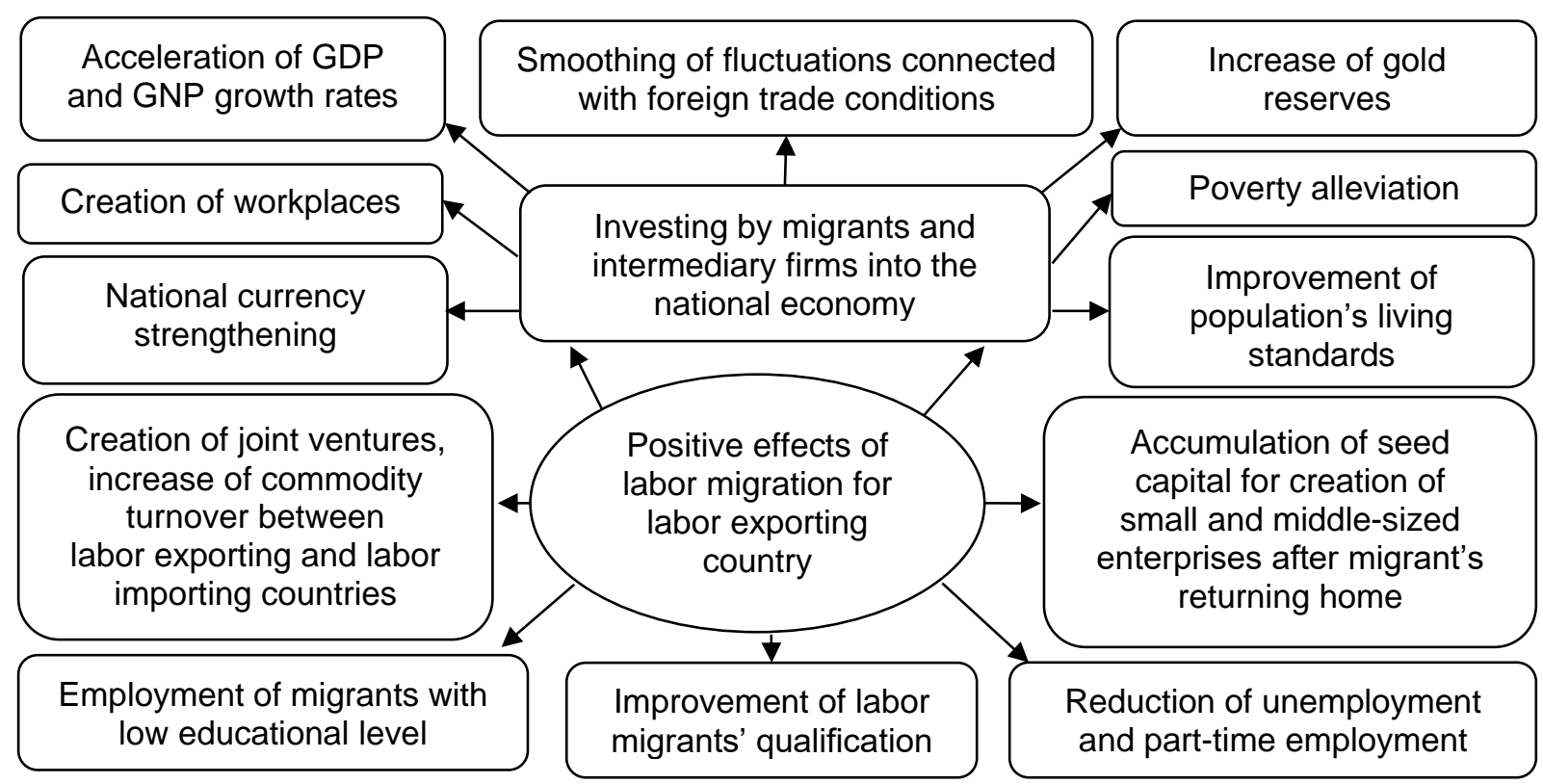

Fig. 3. Positive effects of international labor migration for labor exporting country

1. Reduction of unemployment level and part-time employment in donor countries (Zagulyaev, 2010).

2. Creation of workplaces, improvement of population's living standards and poverty alleviation due to investing by migrants and intermediary firms into national economy of the country of origin. Moreover, remittances strengthen the national currency, smooth the fluctuations of foreign trade conditions, accelerate the GDP and GNP growth rates and increase the gold reserves (Zagulyaev, 2010).

3. Qualification improvement of labor migrants working abroad, their acquiring of new productive and organizational skills that leads to further improvement of labor efficiency and productivity. Staying in the country with more advanced technologies, higher requirements for production processes, higher labor standards increases the general educational and cultural level of migrants, they acquire experience and knowledge that will be needed in their home countries.
4. Employment of migrants with low educational level; creation of business in the service industry of a recipient country.

5. Accumulation of seed capital for the creation of small and middle-sized enterprises after migrant's returning home that contributes to the formation of a middle class in a donor country.

6. Creation of joint ventures, increase of commodity turnover between labor exporting and labor importing countries.

7. Financial aid of labor force recipient countries in order to stimulate remigration.

However, it should be taken into consideration that the positive moments mentioned above don't contribute to long-term development of the labor exporting country.

The major negative effects of labor migration for a donor country are shown in figure 4.

Reduction of the country's productive capacity and low quality of staffing in manufacturing, building, 
transportation and other sectors of the economy because of the outflow of highly qualified specialists and a decrease in a number of economically active population. On this basis, the state invests funds in training of specialists who realize their abilities and create additional value abroad.
Intellectual impoverishment, dissolution of intellectual community and lack of professional labor force that requires expenses on replacing the loss of highly qualified potential.

Constant orientation towards labor export causes the society's disbelief in prospects of national economy's development, leads to decrease of the country's investment level

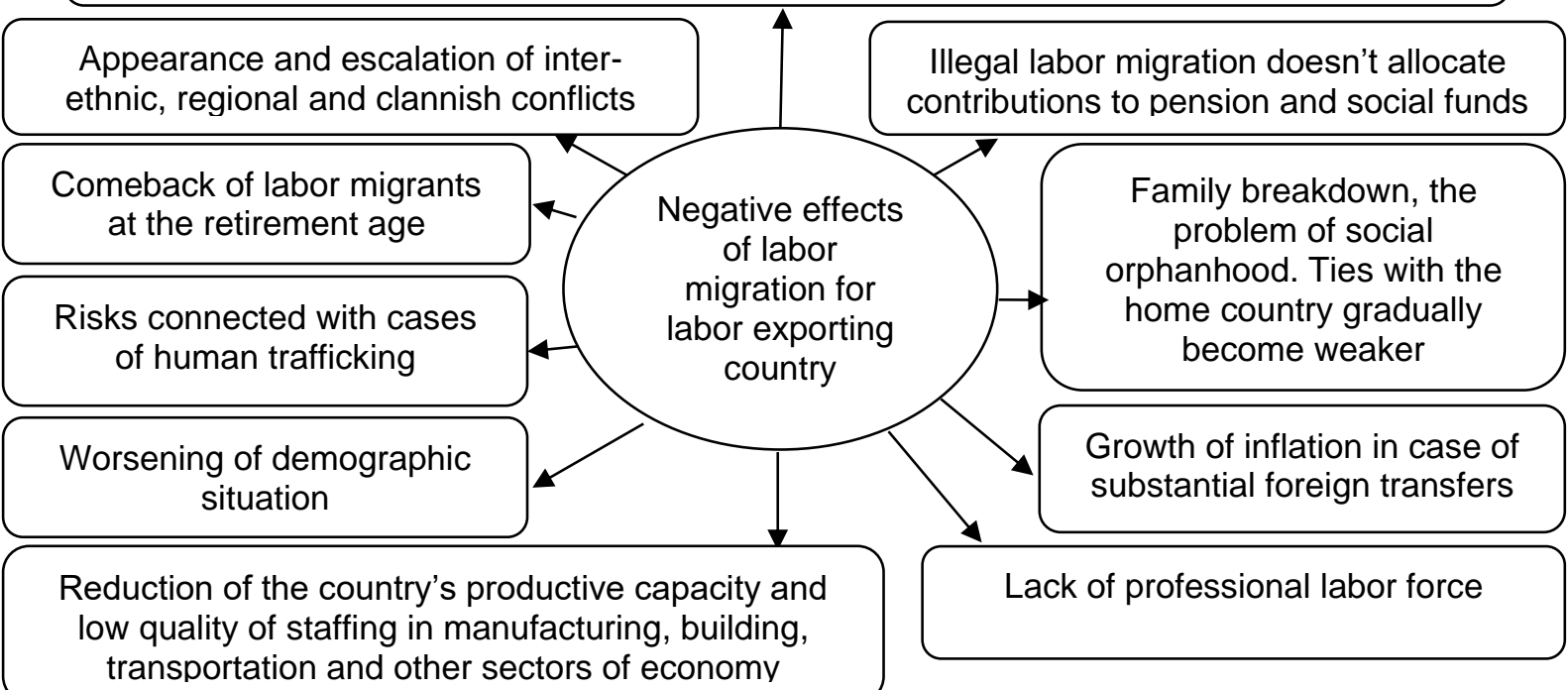

Fig. 4. Negative effects of international labor migration for labor exporting country

Loss of labor force qualification occurs when people are occupied in spheres that are not connected with their field of expertise.

Aggravation of ethnopolitical situation in a donor country, appearance and escalation of interethnic, regional and clannish conflicts as well as weakening of cultural interethnic relations, break in the continuity of national traditions.

Constant orientation towards labor export causes the society's disbelief in prospects of national economy's development, leads to decrease of the country's investment level.

Worsening of demographic situation in a donor country due to emigration and the migrants' receiving the citizenship status in a migration country.

The more migrants live abroad, the less are their remittances, ties with the home country gradually become weaker.

The growth of inflation in case of substantial foreign transfers.
Illegal labor migration doesn't allocate contributions to pension and social funds.

Comeback of labor migrants at the retirement age

Family breakdown, the problem of social orphanhood.

Risks connected with cases of human trafficking (sexual exploitation abroad, slave labor).

All the variety of labor migration effects for both labors exporting and labor importing countries has much in common due to a hardly visible process of convergence in the level of earnings in the migrants' countries of origin and in the countries of their temporary residence. On the one side, the remuneration difference in the benefiting country leads to a reduction of working-age population. The surplus of human capital decreases, and, as a result, its price increases. Migrants having found out their labor price abroad become less flexible while concluding labor contracts in their home countries. Both factors make employers in the migrants' countries of origin take into consideration their remuneration level in the 
countries of preferential emigration. On the other side, the influx of a cheap labor force into the countries with high remuneration level slows down its growth.

\section{CONCLUSIONS}

Thus, labor migration is an inseparable part of the modern labor market that influenced Ukraine to a great extent as it became the focal point of largescale migration flows in the $21^{\text {st }}$ century. The labor migrants' entry to Ukraine may become the reason of local workers' payment reduction and their substitution in the workplaces as well as it may increase the pressure on social infrastructure. It is worth noting that labor migration will have a positive impact on many aspects of Ukrainian economy reducing the problems of employment and creating additional workplaces, as well as increasing labor productivity and efficiency. Simultaneously, because of the outflow of labor resources, the importing country will face demographic problems, shortage of professional labor force and growth of inflation. However, unemployment reduction and investment into the economy of a donor country will contribute to the improvement of economic indicators and the middle-class formation.

At the same time, the migrants' remittances become a substantial source of financing the developing countries' economies as well as the countries with economies in transition.
Considerable amounts of remittances decrease the current transactions deficit, reducing in such a way the possibility of a balance of payments crisis that, in its turn, is the most important condition for economic reforms in the least developed countries. In Ukraine, the migrants' remittances are the factors correcting the balance of payments and stimulating the GDP consumption and increase. Along with it, these funds are conditionally free of charge for Ukrainian economy as compared with the IMF credit tranches and loans, and they are a great potential for the country's banking sector.

Simultaneously, macroeconomic effects of international labor migration lie in the fact that the aggregate world output increases by means of the more efficient use of labor resources due to their redistribution between countries, international migration of labor force causing the tendency to wage parity on the worldwide scale.

The economic effect greatly depends on dynamics of migration processes, their structural characteristics (age-related, qualifying and legal status), type of migration, type of economic activities and the migrants' period of stay in a recipient country that stipulates the necessity of making primarily the structural analysis of migration flows in order to conduct further research concerning the economic effect of international labor migration.

\section{WORKS CITED}

Bollard, A. (n.d.). Remittances and the Brain Drain Revisited. Retrieved from http://siteresources.worldbank.org/INTTRADERESEARCH/Resources/5448241323963330969/8322197-323963890461/Bollard_McKenzie_Morten_Rapoport.pdf

Drinkwater, S. (n.d.). Labor Market and Investment Effects of Remittances. Retrieved from http://www.econ.surrey.ac.uk/Research/scies/papers/2006/labor\%20market.pdf

Haidutskyi, A. (2010). Migratory transfers in the system of the international capital market: a synopsis of the thesis of Doctor of Economics: 08.00.02. The Taras Shevchenko National University of Kyiv.

Kolosnitsyna, M. (2005). International Labor Migration: Theoretical Issues and Regulation. In Journal of the Higher School of Economics(4), pp. 543-565.

Libanova, E., \& Paliy, O. (2004). Labor market and social protection. Kyiv: Osnovy.

Migration and remittances. (2016). Factbook 2016. Retrieved from http://siteresources.worldbank.org/INTPROSPECTS/Resources/3349341199807908806/4549025-1450455807487/Factbookpart1.pdf

Migration models. (n.d.). Retrieved from http://www.novelguide.com/a/discover/epop_02/epop_02_00230.html

Mochernyi, S. (2001). Economic Encyclopedia (Vol. 3). Kyiv: The Academy. 
Poirine, B. (1997). A Theory of Remittances as an Implicit Family Loan Arrangement. World Development, 25(4), pp. 589-611.

Shevchuk, V. (n.d.). Migration processes as an instrumental factor of the regional trap of stagnation. Retrieved from http://mev.lac.lviv.ua/downloads/vyklad/shevch/region-07-5Lutsk15.pdf

Skilled immigration in OECD regions. (n.d.). Retrieved from http://www.oecd-ilibrary.org/urban-ruraland-regional-development/oecd-regions-at-aglance-2011/skilled-immigration-in-oecdregions_reg_glance-2011-15-enjsessionid=qtyo0kbglln0.x-oecd-live-01

Slobodian, O. (n.d.). What do we know about the regional distribution of remittances? Retrieved from http://www.cedos.org.ua/uk/migration/shcho-my-znaiemo-pro-rehionalnyi-rozpodil-hroshovykhperekaziv

State Statistics Service of Ukraine. (n.d.). Retrieved from http://www.ukrstat.gov.ua/

Sytarchuk, E. (2010). The economic functions of migration in developing the capacity of the labor market. In Terra Economicus, 8. P. 2(4), pp. 25-29.

The Major Tendencies in the Labor Market. (2015). Retrieved from http://www.dcz.gov.ua/statdatacatalog/document?id=350794

Zagulyaev, D. (2010). The concept of the international wage workers labor-market regulation from the point of view of the rental character of the world economy. In Bulletin of South Ural State University(7), pp. 4-10.

Zayonchkovskaya, Z., Molodikova, I., \& Mukomel, V. (2007). The methodology and methods of studying migration processes. The interdisciplinary manual. Moscow: The Centre for Migration Research.

Received for publication: $\quad$ 09.06.2017

Revision received: $\quad 18.09 .2017$

Accepted for publication: $\quad 10.01 .2018$

\section{How to cite this article?}

Style - APA Sixth Edition:

Melnyk, T., \& Losheniuk, O. (2018, Jan 15). Economic effects of dynamics in migration processes. (Z. Čekerevac, Ed.) MEST Journal, 6(1), 68-78. doi:10.12709/mest.06.06.01.08

Style - Chicago Sixteenth Edition:

Melnyk, Tetyana, and Oksana Losheniuk. 2018. "Economic effects of dynamics in migration processes." Edited by Zoran Čekerevac. MEST Journal (MESTE) 6 (1): 68-78. doi:10.12709/mest.06.06.01.08.

Style - GOST Name Sort:

Melnyk Tetyana and Losheniuk Oksana Economic effects of dynamics in migration processes [Journal] // MEST Journal / ed. Čekerevac Zoran. - Toronto : MESTE, Jan 15, 2018. - 1 : Vol. 6. - pp. 68-78.

Style - Harvard Anglia:

Melnyk, T. \& Losheniuk, O., 2018. Economic effects of dynamics in migration processes. MEST Journal, 15 Jan, 6(1), pp. 68-78.

Style - ISO 690 Numerical Reference:

Economic effects of dynamics in migration processes. Melnyk, Tetyana and Losheniuk, Oksana. [ed.] Zoran Čekerevac. 1, Toronto : MESTE, Jan 15, 2018, MEST Journal, Vol. 6, pp. 68-78. 